\title{
Influences of Different Soil Erosion Control Methods on Bean Production Characteristics and yield
}

\author{
KWIZERA CHANTAL ${ }^{1}$, ndihokubwayo Soter ${ }^{1}$, Basil T.Iro Ong' or ${ }^{2}$, HABONIMANA \\ BERNADETTE $^{1}$, Salvator Kaboneka ${ }^{1}$, Ndimubandi Jean ${ }^{1}$, Jos Van Orshoven ${ }^{3}$, \\ Rishirumuhirwa Théodomir ${ }^{1}$, Sevérin Nijimbere ${ }^{1}$, and Desiré Niyibaruta ${ }^{1}$ \\ ${ }^{1}$ University of Burundi \\ ${ }^{2}$ Masinde Muliro University of Science and Technology \\ ${ }^{3}$ University of Leuven
}

July 6, 2020

\begin{abstract}
Erosion negatively affects crop yields and decreases crop productivity. It removes nutrients, reduces rooting depth, and damages soil structure, resulting in negative nutrient balances and lower crop yields. A study for two years was conducted using three soil erosion control methods to appraise the method which could effectively control erosion and improve bean production characteristics on a hill more prone to erosion. Designed on three different plots ( P1, P2, P3) divided in four sub plots (S1, S2, S3, S4), these methods were traditional plowing method (M1); anti-erosive hedges planting method (M2) and anti-erosive hedges coupled with anti-erosive ditches (M3). The recorded parameters were the number of: pods, full pods and grains, as well as the average yield weight. After analysis with SPSS and Advanced excel, results showed no significant difference between M1 and M2 but highlighted the significant effects of M3 method in improving the number of: pods, full pods and grains. Likewise, this method has somehow enhanced the average yield weight. These outcomes suggest M3 as the most effective method in enhancing bean production characteristics and yield at Buhoro hill.
\end{abstract}

\section{Hosted file}

Article Erosion control on Yield new file.doc available at https://authorea.com/users/ 340120/articles/467269-influences-of-different-soil-erosion-control-methods-on-beanproduction-characteristics-and-yield 